\title{
PENERAPAN TEKNOLOGI PEMBUATAN PILUS DENGAN FORTIFIKASI RUMPUT LAUT
}

\author{
Salnida Yuniarti Lumbessy ${ }^{1 *}$, Nunik Cokrowati ${ }^{1}{ }^{1}$, Nanda Diniarti $^{1}{ }^{1}$, Dewi Nur'aeni \\ Setyowati ${ }^{1)}$ dan Rahmi Sri Ramadhani ${ }^{2)}$ \\ 1)Program Studi Budidaya Perairan, Universitas Mataram \\ 2)Fakultas Ekonomi dan Bisnis, Universitas Mataram \\ Jalan Majapahit Nomor 62, Mataram 83125 \\ *) alamat korespondensi : alyachali@gmail.com
}

\begin{abstract}
ABSTRAK
Kelompok Usaha Bersama "Garing Seledri" dan "Daun Singkong" merupakan bentuk perkumpulan kegiatan warga di Desa Toya, Kecamatan Aikmel, Kabupaten Lombok Timur yang melakukan kegiatan pengolahan kerupuk sejak tahun 2010 dengan potensi produksi kerupuk rata-rata 1 kwintal setiap kali produksinya. Namun produksi kerupuk tersebut masih berdasarkan atas pesanan sehingga kegiatan produksi tidak dilakukan setiap hari. Akibatnya masih banyak waktu luang yang dimiliki oleh ibu-ibu yang sebenarnya bisa mereka manfaatkan untuk kegiatan produksi selain kerupuk tersebut, seperti produksi pilus rumput laut. Untuk itu, usaha pengenalan produk "pilus rumput laut" yang akan dilakukan melalui kegiatan pengabdian ini bisa menjadi alternatif produksi bagi ibu-ibu di desa Toya pada saat tidak melakukan produksi kerupuk. Pengolahan pilus rumput laut menjadi pilihan dalam kegiatan ini karena fasilitas yang digunakan untuk produksinya sama dengan yang digunakan dalam pembuatan kerupuk sehingga diharapkan dengan fasilitas yang ada maka mitra dapat menghasilkan produk yang bervariasi (kerupuk dan pilus rumput laut). Tujuan dari kegiatan ini adalah melakukan alih pengetahuan dengan aktif memberikan pembelajaran, pelatihan dan pendampingan kegiatan produksi pilus rumput laut. Metode pelaksanaan kegiatan ini meliputi pendampingan, rancang bangun dan pelatihan produksi. Hasil kegiatan pengabdian kepada masayarakat ini adalah bertambahnya pengetahuan mitra dalam membuat pilus rumput laut dan hasil produksi yang lebih baik.
\end{abstract}

Kata Kunci : desa toya kecamatan aikmel, fortifikasi, pilus, rumput laut 


\section{PENDAHULUAN}

Kelompok Usaha Bersama
"Garing Seledri" dan "Daun
Singkong" merupakan bentuk
perkumpulan kegiatan warga di Desa
Toya, Kecamatan Aikmel, Kabupaten
Lombok Timur yang masuk dalam
kategori industri kecil yang berbentuk
home industri. Kedua Kelompok
Usaha Bersama ini telah melakukan
kegiatan pengolahan kerupuk sejak
tahun 2010. dengan potensi produksi
kerupuk rata-rata 1 kwintal setiap kali produksinya dan kegiatan produksi dilakukan tergantung pada pesanan saja. Oleh karena itu produksi tidak dilakukan setiap hari sehingga masih banyak waktu luang yang bisa dimanfaatkan untuk melakukan kegiatan produksi selain kerupuk, yaitu memproduksi pilus rumput laut. Pengolahan pilus rumput laut menjadi pilihan dalam kegiatan ini karena fasilitas yang digunakan untuk produksinya sama dengan yang digunakan dalam pembuatan kerupuk sehingga diharapkan dengan fasilitas yang ada maka mitra dapat menghasilkan produk yang bervariasi (kerupuk dan pilus rumput laut).

Pilus rumput laut merupakan salah satu jenis produk olahan kering atau "snack" dengan bahan rumput laut yang berserat tinggi. Produk ini memiliki cita rasa yang gurih dan tekstur yang renyah. Meningkatnya produksi rumput laut di NTB memberikan peluang usaha untuk pengembangan produk olahan berbahan dasar rumput laut, seperti pilus. Pemanfaatan rumput laut dalam pembuatan pilus ini dapat meningkat nilai gizi produk karena rumput laut memiliki kadungan vitamin, betakaroten dan mineral seperti kalium, kalsium dan fosfror yang baik bagi kesehatan

Kendala pembinaan baik dalam aspek pengetahuan dan alih teknologi proses pengolahan pilus rumput laut belum mendapat pembinaan dan pendampingan secara berkelanjutan. Melihat potensi sumberdaya alam dan sosialbudaya maka program pembinaan pengembangan pilus rumput laut akan sangat membantu dalam pengembangan kesejahteraan melalui usaha produktif dan diversifikasi pangan di Desa Toya, Kecamatan Aikmel, Kabupaten Lombok Timur. Kendala pengetahuan dan sarana produksi menjadi faktor utama dalam pengembangan pilus rumput laut di kelompok "Garing Seledri" dan "Daun Singkong", sedangkan ketenagakerjaan dari penduduk lokal di Desa Toya siap dalam mengembangkan pilus rumput laut.

\section{METODE KEGIATAN}

Kegiatan pengabdian ini dilaksanakan pada Kelompok "Garing Seledri" dengan jumlah anggota 15 orang dan kelompok "Daun 
Singkong" dengan jumlah anggota 10 orang, di Desa Toya, Kecamatan Aikmel, Kabupaten Lombok Timur, NTB. Kedua kelompok ini dipilih karena masih aktif memproduksi kerupuk dan bersedia untuk menjadi mitra pada kegiatan ini.

Metode pelaksanaan kegiatan pengabdian ini meliputi pendampingan, rancang bangun dan pelatihan produksi.

1. Pendampingan. Kegiatan ini dilakukan dalam bentuk pendampingan langsung kepada kedua mitra. Kegiatan pendampingan yang dilakukan meliputi kegiatan observasi, brainstorming, alih pengetahuan secara teoritis serta upaya perbaikan teknik pengemasan. Kegiatan observasi dilakukan untuk menggali informasi mengenai aktivitas usaha kerupuk yang dilakukan mitra melalui kegiatan survei dan pemantauan. Dari kegiatan observasi ini kemudian dilakukan brainstorming melalui diskusi untuk membuka mindset mitra untuk melakukan usaha pilus rumput laut karena fasilitas yang digunakan untuk produksinya sama dengan yang digunakan dalam pembuatan kerupuk sehingga diharapkan dengan fasilitas yang ada maka mitra dapat menghasilkan produk yang bervariasi (kerupuk dan pilus rumput laut)

2. Rancang Bangun. Kegiatan rancang bangun yang dilakukan adalah pembuatan paket teknologi berupa alat pencetak pilus rumput laut dan alat pengemas (sealer). Alat pencetak pilus dipesan di bengkel Pandawa Bandung sebanyak 1 buah yang akan digunakan secara bersama oleh kedua mitra yang terlibat dalam kegiatan pengabdian ini. Sedangkan alat pengemas (sealer) dapat diperoleh di pasaran dan setiap mitra memperoleh 1 alat pengemas (sealer).

3. Pelatihan Produksi. Kegiatan pelatihan produksi meliputi : Pembuatan adoanan pillus rumput laut (Gambar 1.) dan pelatihan penggunaan alat pencetak pilus dan alat pengemas (sealer). 


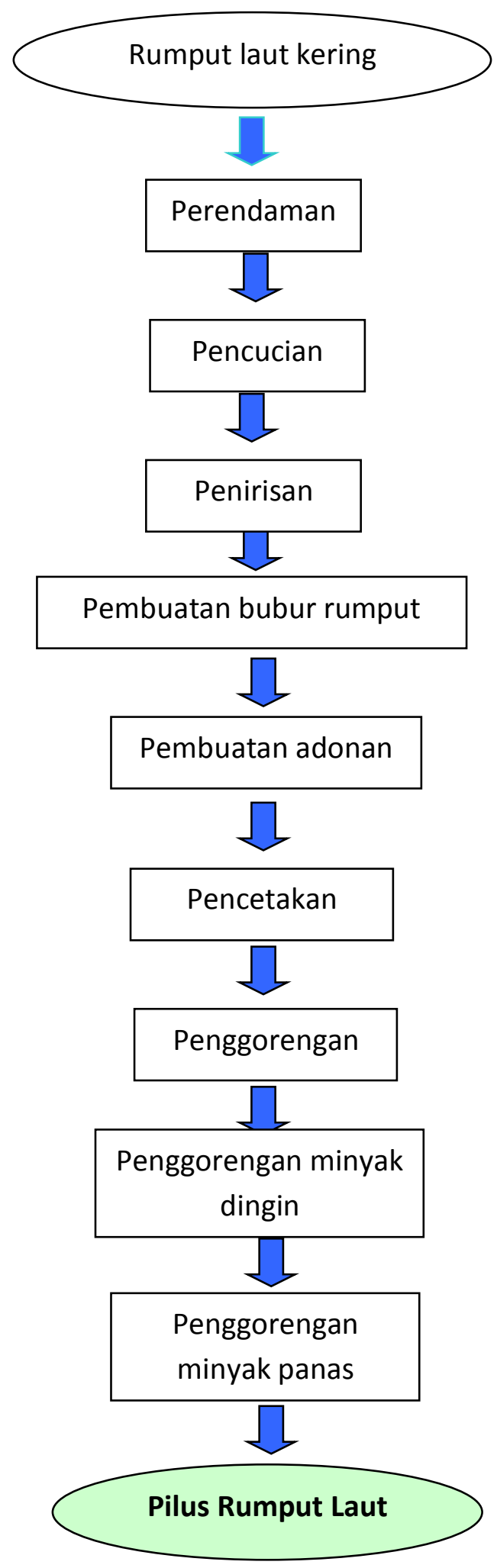

Gambar 1. Prosedur Pembuatan Pilus Rumput Laut 


\section{HASIL DAN PEMBAHASAN}

Mitra pengusaha dalam
kegiatan pengabdian ini adalah pengusaha kerupuk yang semuanya berada di wilayah RT 01, Dusun Toya Lauq, DesaToya, Kecamatan Aikmel, Lombok Timur (2 pengusaha). Dusun Toya Lauq merupakan satu dari Sembilan dusun di Desa Toya yang terletak kurang lebih $2 \mathrm{~km}$ dari ibukota kecamatan dengan lama waktu tempuh 5 menit. Sedangkan jarak dari ibukota kabupaten sejauh kurang lebih $20 \mathrm{~km}$ dengan lama waktu tempuh 30 menit. Sementara itu jarak dari ibukota Propinsi kurang lebih $60 \mathrm{~km}$ dengan lama waktu tempuh 2 jam. Jumlah penduduk desa Toya adalah 8273 jiwa dengan jumlah kepala keluarga sebanyak 2605 KK. Mayoritas penduduknya bermata pencaharian sebagai petani. Kedua pengusaha ini tidak tergabung dalam suatu koperasi atau paguyuban tertentu. Sebelum menekuni usaha kerupuk ini mereka pernah menekuni beberapa pekerjaan yang cukup beragam, seperti : petani, buruh pada usaha kerupuk sebelumnya, dan ibu rumah tangga.

Kegiatan ini dimulai dengan pendampingan langsung kepada kedua mitra melalui kegiatan observasi, brainstorming dan diskusi, alih pengetahuan secara teoritis serta upaya perbaikan teknik pengemasan. Kegiatan observasi dilakukan terhadap 3 pengusaha mikro yang memperoduksi kerupuk. Dari hasil observasi ini dapat disimpulkan bahwa usaha kerupuk yang dilakukan oleh mitra masih merupakan usaha perorangan dengan semua sistem pengelolaannya berada di tangan pemiliknya. Belum ada sistem manajemen yang mendistribusikan tugas dan tanggung jawab kegiatan usaha. Semua kegiatan usaha masih dilakukan sendiri oleh pemilik, mulai dari kegiatan mencari bahan baku, memasarkan hingga sistem keuangan. Selain itu juga diperoleh informasi bahwa produksi kerupuk tersebut masih berdasarkan atas pesanan sehingga kegiatan produksi tidak dilakukan setiap hari apalagi ketika musim hujan mereka terkendala dengan proses pengeringan sehingga terkadang tidak ada produksi ketika musim hujan tersebut. Akibatnya masih banyak waktu luang yang dimiliki oleh ibu-ibu yang sebenarnya bisa mereka manfaatkan untuk kegiatan produksi selain kerupuk tersebut.

Dari kegiatan observasi ini kemudian dilakukan brainstorming dengan cara berdiskusi dengan mitra untuk membuka mindset mereka untuk melakukan usaha pembuatan pillus rumput laut karena sebagian besar fasilitas yang digunakan untuk produksi pilus sama dengan yang digunakan dalam pembuatan kerupuk sehingga diharapkan dengan fasilitas yang ada maka mitra dapat 
menghasilkan produk yang bervariasi (kerupuk dan pilus rumput laut). Dari hasil brainstorming dan diskusi ini ternyata mitra sangat antusias dan tertarik untuk membuat pillus rumput laut.

Upaya pendampingan lain
yang dilakukan berupa alih
pengetahuan secara teoritis. Kegiatan yang dilakukan pada tahap ini meliputi persiapan modul kegiatan dan pelatihan teoritis. Pembuatan modul kegiatan diselesaikan dalam waktu 4 (empat) minggu yang terdiri atas modul Manajemen Produksi, modul penjaminan mutu pangan, modul manajemen keuangan dan modul pengoperasian dan perawatan alat. Modul yang dibuat oleh tim pengusul diorientasikan kepada kondisi hasil peninjauan usaha, yaitu seringkas dan semudah mungkin. Modul yang sudah siap kemudian digunakan untuk alih pengetahuan secara teoritis terlebih dahulu karena mitra yang terlibat dalam kegiatan pengabdian ini belum pernah memproduksi pillus rumput laut sebelumnya. Pelaksanaan program alih pengetahuan teoritis ini lebih banyak diarahkan kepada penekanan terhadap metode pembuatan pillus rumput laut yang baik sehingga kelompok "Garing Seledri" dan "Daun Singkong" memahami aplikasi dasardasar proses keamanan pangan. Hal ini untuk memberikan jaminan kekuatan moril bagi khalayak sasaran untuk memberikan deseminasi kepada masyarakat sekitar lokasi kegiatan (Gambar

2)

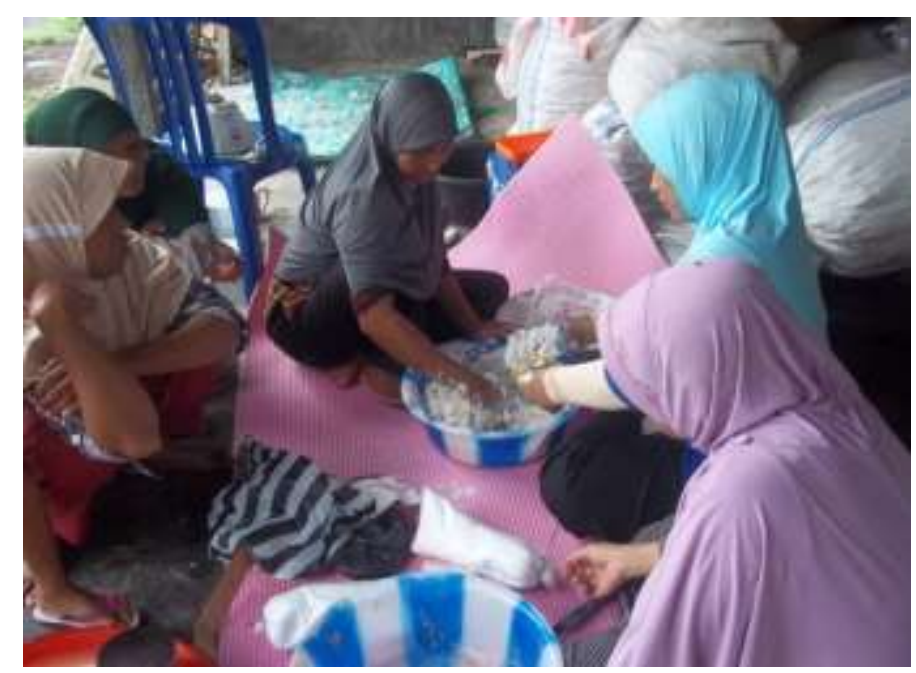

Gambar 2. Pelatihan Pembuatan Pilus Rumput Laut

Bentuk pendampingan yang terakhir adalah perbaikan teknik pengemasan dan legalitas produk. Berdasarkan hasil monitoring di lokasi ditemukan bahwa pengemasan produk masih menggunakan plastic PE (Polyethylene) dan direkatkan dengan menggunakan api lilin sehingga kurang baik dalam aspek penyimpanan dan nilai jual. Setelah 
kegiatan pengabdian ini maka mitra telah terlatih dalam menggunakan alat pengemas yang baik (sealer). Dengan perbaikan ini, kemasan menjadi lebih baik dan waktu pengepakan menjadi lebih cepat dari sebelumnya (Gambar 3.) Untuk legalitas produk, mitra sudah didaftarkan di Dinas Kesehatan (Dinkes) Lombok Timur dan sedang menunggu pelatihan sebagai syarat untuk mendapatkan nomor sertifikat produk.

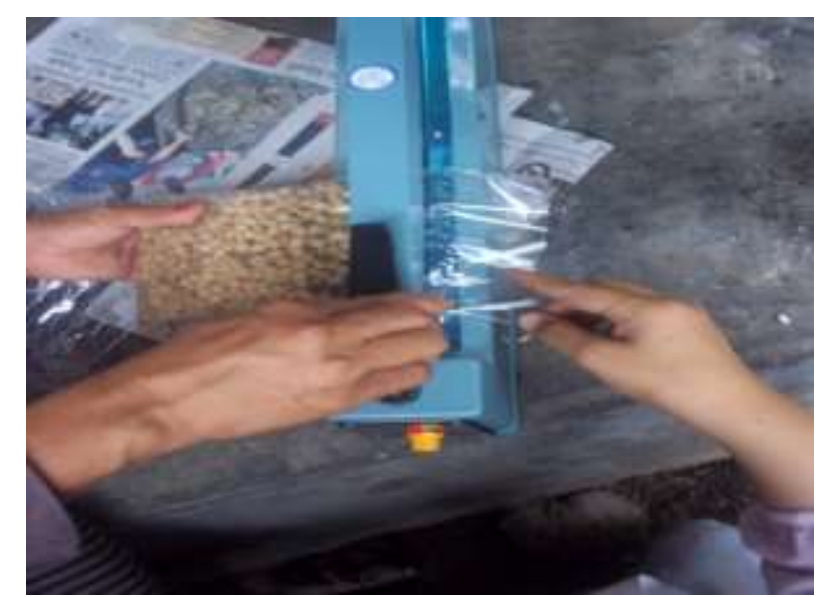

Gambar 3. Pelatihan Penggunaan Alat Pengemasan (Sealer)

Kegiatan rancang bangun dapat diperoleh di pasaran dan setiap yang dilakukan adalah pembuatan mitra memperoleh 1 alat pengemas paket teknologi berupa alat pencetak (sealer). Sebelum melakukan alih pillus rumput laut dan alat pengemas teknologi, tim pengabdian melakukan (sealer). Alat pencetak pillus dipesan optimalisasi penggunaan alat di bengkel Pandawa Bandung pencetak pillus rumput laut di sebanyak 1 buah yang akan Laboratorium Perikanan, Program digunakan secara bersama oleh Studi Budidaya, Unram untuk kedua mitra yang terlibat dalam mendapatkan formulasi adonan pillus kegiatan pengabdian ini (Gambar 4.) rumput laut yang dapat dicetak Sedangkan alat pengemas (sealer) dengan hasil cetakan yang lebih baik.

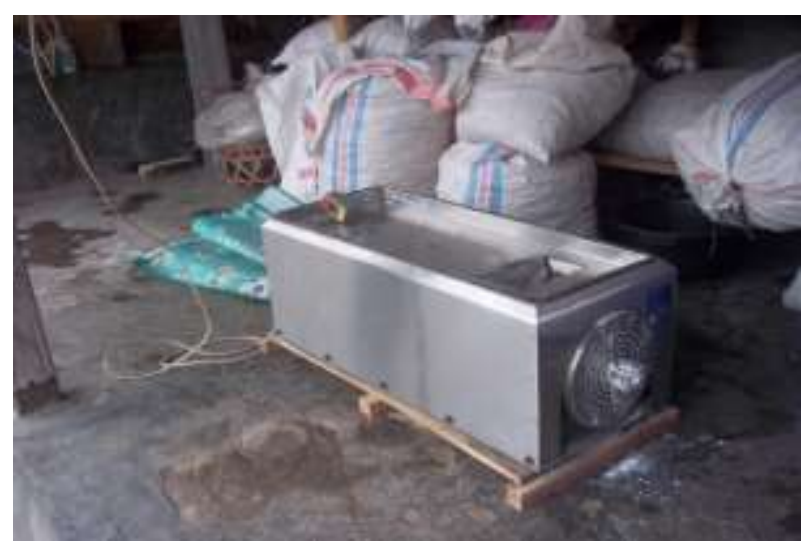


Gambar 4. Mesin Pencetak Pillus Rumput Laut

Pada pelatihan pembuatan laut, dengan kondisi adonan pillus adonan pilus rumput laut mitra sangat antusias dan tidak ada kendala yang berarti karena sebagian besar mitra adalah kaum ibu-ibu dan mereka sudah terbisa dalam mengolah makanan. Pada kegiatan ini, peserta dilatih untuk mengetahui formulasi yang tepat dan teknik pembuatan pilus berbahan dasar rumput laut yang baik ditinjau dari rasa, warna, tekstur, dan penampakan dari produk tersebut, serta kemasan yang dapat diterima oleh konsumen. Pada pelatihan penggunaan alat pencetak pillus, mitra tidak mengalami kendala yang berarti karena alat sudah dibuat dengan sistem pengoperasian yang sangat sederhana. Kapasitas alat pencetak pilus adalah $125 \mathrm{~kg} / \mathrm{jam}$, sehingga apabila diasumsikan bahwa waktu kerja efektif adalah 8 jam maka sekali produksi akan dapat harus masuk secara kontinu ke dalam mesin pencetak pillus.

Secara umum kegiatan pengabdian ini telah berhasil meningkatkan motivasi dan pengetahuan peserta dalam membuat pilus rumput laut. Hal ini dapat dilihat dari antusiasme peserta dalam menyimak materi dan praktek yang diberikan serta adanya saran dan masukan dari peserta terkait pelaksanaan kegiatan penyuluhan. Bentuk pillus yang dihasilkan oleh peserta selama pelatihan memiliki penampilan organoleptik yang lebih baik (permukaan pillusnya lebih halus dan warnanya lebih putih) (Gambar 5.) dihasilkan $1000 \mathrm{~kg}$ pillus rumput

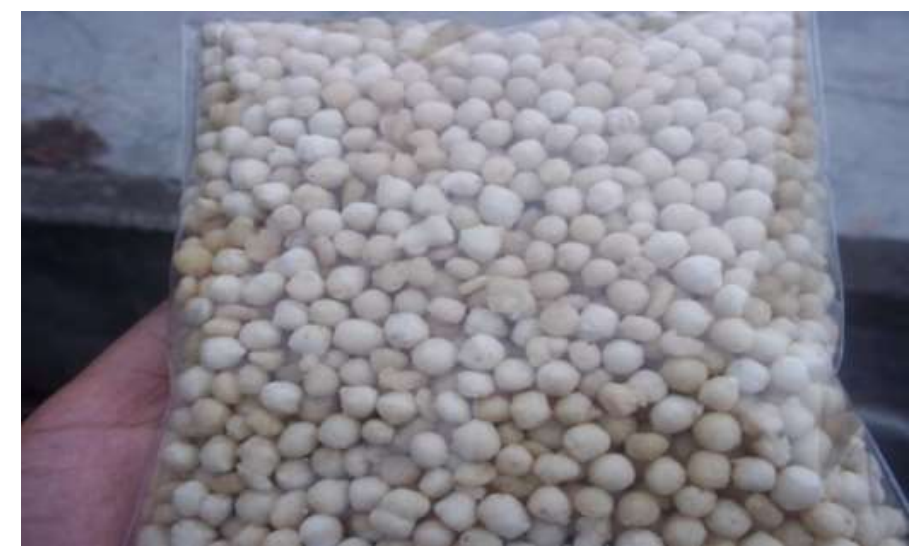

Gambar 5. Produksi Pilus yang dihasilkan oleh Mitra 


\section{KESIMPULAN DAN SARAN}

\section{Kesimpulan}

Kesimpulan dari kegiatan

Pengabdian Kepada Masyarakat "

Penerapan Teknologi Pembuatan

Pilus Dengan Fortifikasi Rumput Laut" adalah :

1. Penampilan organoleptik pillus yang dihasilkan oleh mitra menjadi lebih baik (permukaan pillusnya lebih halus dan warnanya lebih putih). Selain itu, dalam proses penggorengan mereka hanya menggunakan satu tahap penggorengan saja. Hal ini tentu lebih mengefisiensikan waktu kerja dan biaya produksi pembuatan pillus rumput laut.

2. Kapasitas alat pencetak pilus adalah $125 \mathrm{~kg} / \mathrm{jam}$, sehingga apabila diasumsikan bahwa waktu kerja efektif adalah 8 jam maka sekali produksi akan dapat dihasilkan $1000 \mathrm{~kg}$ pillus rumput laut, dengan kondisi adonan pillus harus masuk secara kontinu ke dalam mesin pencetak pillus.

Saran

$$
\text { Disarankan kepada dinas }
$$
terkait (Dinas Perindustrian dan Perdagangan, Dinas Kesehatan) dan pihak lain agar hasil yang dicapai selama ini terus dikembangkan, sehingga kesinambungan program tetap terjamin.

\section{UCAPAN TERIMA KASIH}

Ucapan terimakasih kepada semua pihak yang mendukung kegiatan pengabdian kepada masyarakat sehingga dapat berjalan dengan lancar. Kegiatan pengabdian kepada masyarakat dibiayai dengan Dana DIPA DIT.LITABMAS Dikti, yang dikelola oleh Universitas Mataram dan kerjasama dari mitra di Desa Toya, Kecamatan Aikmel, Lombok Timur.

\section{DAFTAR PUSTAKA}

Abdullah, 2011. Resep Pilus Rumput Laut. Pelatihan Teknik Produksi Rumput Laut. Badan Diklat Industri Provinsi Sulawesi Selatan.

Meiyas, F., Tarigan N., Efruan, G. K., Sitaniapessy, D. A., dan pati, D. U. 2019. Pelatihan Pembuatan Stik dan Pilus Rumput Laut pada Kelompok Usaha Kelurahan Kambajawa. Jurnal PKM : Pengabdian Kepada Masyarakat 02(03) : $212-220$. 